\title{
Evaluation of Rainwater Harvesting System On Skin- Deo Factory Cikarang
}

\author{
Putri Anggun Sari ${ }^{1}$, Dodit Ardiatma ${ }^{2}$, Hadi Ismanto ${ }^{3}$ \\ Pelita Bangsa University \\ poetrispt@pelitabangsa.ac.id ${ }^{1}$,doditardiatma@pelitabangsa.ac.id ${ }^{2}$, ismantohadi20@gmail.com $^{3}$
}

\begin{abstract}
The purpose of this study is to determine the effectiveness of the construction of rain water harvesting buildings or rain water harvesting with a reservoir system or the construction of a ground water tank related to the distribution system of the raw water network itself, the operation and maintenance of the water and to test the quality of the water collected in the building ground water tank. Research conducted using quantitative descriptive methods by collecting data related to the dimensions of Rainwater Harvesting $(\mathrm{PAH})$, data on the roof area of water catching the whole section that captures water to the ground water tank, rainfall data from 2007 to 2017 as its inflow value, and raw water needs of usage in the factory area. From the results of this study it was found that the potential for groundwater savings in a period of 3 years was $45.3 \%$, the water quality from the results of laboratory tests, and physical tests of rainwater were included in the first class criteria of water quality whose designation could be used for raw water drink, the water distribution system used is the down feed system, the water treatment used (filtering of solid material, siltation, absorption). However, in the factory area itself the water is only limited to being used for production operations, including bathroom needs, gardening, cooling tower and certainly to reduce runoff caused by rainwater itself. The conclusion of this study is that the expected design criteria are in accordance with current needs and can meet existing needs and are able to accommodate rainfall runoff.
\end{abstract}

Keywords: Evaluation, Rainwater Harvesting, Skin-Deo

\section{Introduction}

Water is one of the main needs for humans and healthy plant growth.. Water supply security has become a major concern worldwide due to ever-increasing water demand resulting from population growth, rapid urbanisation and industrial development. Moreover availbility of water resources is decreasing due to water pollution around the world as consequence of increasing urbanisation and industrialisation [1].

Good water sources from springs, rivers, wells, lakes, seas and rainwater are owned by so many and extensive in Indonesia. In general, abundant water in Indonesia, especially those sourced from rain water with an average rainfall of $2000-4000 \mathrm{~mm} /$ year means that if rain water is "collected" for one year it will be as high as 2-4 meters. Therefore, there are several efforts that can be done, namely by carrying out a rain harvesting system. Even in the international world is now an important part of the global agenda of environmental water resources management in order to tackle water inequality in the rainy and dry season (lack of water), a source of shortages of clean water supply to the world's population, and prevention of floods and droughts.

In general, risk of water inadequacy is lesser in developed countries than developing countries [2]. But supplying adequate water to the cities requires a notable amount of other 
resources such as energy and infrastructure. Hence even countries with good water balance conditions between demand and available water resources are continuously evaluating alternatives (e.g. reduction in water consumption and identification of new sources to supply water) to optimise water management. One of the most common and adaptable alternative sources is the rainwater for use in the buildings, in particular residential buildings [3], [4], [5].

Rainwater is used as either the principal or a supplementary source of water to the main water supply system in a residential building [6]. One of the existing water conservation methods that already exist for households or other needs is rainwater harvesting, which is a source of collecting, storing rainwater and utilizing existing runoff water. Rainwater harvesting is a method of catching or collecting and utilizing rainwater optimally. Rain harvesting can be defined as an effort to collect rain water for clean water needs and or absorb rainwater into the ground to cope with floods and drought. Most techniques for collecting water usually use large water sources such as rivers and groundwater (eg wells and irrigation systems), and require large-scale investment. But in many countries of the world, various small-scale and simple methods have been developed to capture and collect runoff water used for a variety of productive purposes both for households or for other needs such as industry. If this surface runoff is left alone it can cause soil erosion, and this run-off flood / standing water can be harvested and utilized.

\section{Literatur Review}

\subsection{Rainwater Harvesting}

Rainwater harvesting is an activity to collect rainwater locally and store it through various technologies, for future use to meet the demands of human consumption or human activities [7]. Another definition of rainwater harvesting is the collection, storage and distribution of rainwater from the roof, for use inside and outside the home or business. Sustainable drainage system is a technique used in managing rainwater that falls on the surface of roofs and other surfaces through a series of actions, whose main purpose is to control the flow rate and volume of surface runoff to reduce the risk of flooding and water pollution and in order to reduce pressure on the drainage network (sewerage network) and in order to improve biodiversity and local convenience (localamenity). The basic concept of developing sustainable drainage is to improve water use, minimize losses and improve and conserve the environment. Thus, the main priority of activities must still be aimed at managing runoff [7].

Rainfall is the main variabel of interest for a RWHS system [2], especially temporal variability of rainfall is the critical governing factor in its performance. Design of RWHS is generally concerned with determining the optimum tank size to ensure water supply for the anticipated use. An oversized tank is loss of resources (e.g. energy, time, and money); on the other hand and undersized tank will not be able to fulfil the required water de- mand. Therefore, needs of households and the characteristics of the geographical locations should be considered when designing a RWHS. Many studies are available in literature on the benefits, design, performance and feasibility analysis of a RWHS, for example in Germany [8], in China [9], in Brazil [10], in USA [11], [12], in Italy [13], in Virginia [14], in Mexico [15] and in Australia [16[, [17]. 


\subsection{Inflow}

The main equations used, including; surface runoff discharge using the Rational Method with equations. Inflow (input) is the volume of rainwater that falls on the roof of a building and is accommodated. The formula used to obtain inflow is a rational method based on the following equation:

$\mathrm{Q}=0,287$. .C.I.

$\mathrm{Q}=$ runoff discharge plan $\left(\mathrm{m}^{3 /} \mathrm{s}\right) \mathrm{C}=$ runoff coefficient

$\mathrm{I}=$ rain intensity at the same duration as the concentration time and a certain rain return period $(\mathrm{mm} / \mathrm{h})$

$\mathrm{A} \quad=$ area of drainage (hectare)

Runoff coefficient (C) is determined using the Weighted Runoff Coefficient formula or C equivalent, with the equation [18].

\subsection{Calculation of Potential Amount of Water that Can be Harvested}

The potential of the water harvesting potential from a roof building can be known through simple calculations [19], as follows:

harvestable water $=$ Area $x$ rainfall $x$ runoff coefficient. In the illustration in the figure below for a $200 \mathrm{~m}^{2}$ rain catchment area, $500 \mathrm{~mm}$ annual rainfall, the amount of water that can be harvested is determined as follows:

a) With an area of $=200 \mathrm{~m}^{2}$ and the amount of annual rainfall $=500 \mathrm{~mm}$, the volume of rain water that falls in the area is : $20.000 \mathrm{dm}^{2} \times 5 \mathrm{dm}=100.000$

b) Assuming that only $80 \%$ of the total rain can be harvested $(20 \%$ is lost due to evaporation or leakage), then the volume that can be harvested: $100.000 \times 0,8=80.0001 / y$

by using the following equation:

$\mathrm{V}=\mathrm{R} \times \mathrm{A} \times \mathrm{kV}$

$\mathrm{V}=$ the volume of water accommodated $\left(\mathrm{m}^{3}\right) \mathrm{R}=$ rainfall $(\mathrm{m})$

A $=$ catchment area $\left(\mathrm{m}^{2}\right)$

$\mathrm{k} \quad=$ water runoff coeficient

\section{Research Method}

This research method is a way to obtain relevant data to evaluate and also identify the concept of design criteria and the application of rainwater harvesting technology in the Skin Deo factory and also evaluating the system of rainwater harvesting, which already exists to accommodate rainwater and runoff discharge. In this study primary data collection will be sourced from surveys and also secondary data collected from literature studies and related agencies. The survey conducted in this study is obervasation conducted in the environment of Skin Deo Cikarang factory by observing the physical condition of the granary, the catchment 
area and the need for raw water. The analytical method used in this research is quantitative descriptive method. This method is in the form of data collection, data analysis, and interpretation of the results of the analysis to obtain information for conclusions.

\section{Result And Discussion}

From the research results of the rainwater harvesting system, this skin deo factory use a Cistern / Catchment system by utilizing the roof media to catch / harvest rainwater directly such as gutters, downspout pipes, first rainwater pouring channels (first flush diverters) and rainwater collection units (Figure.1).

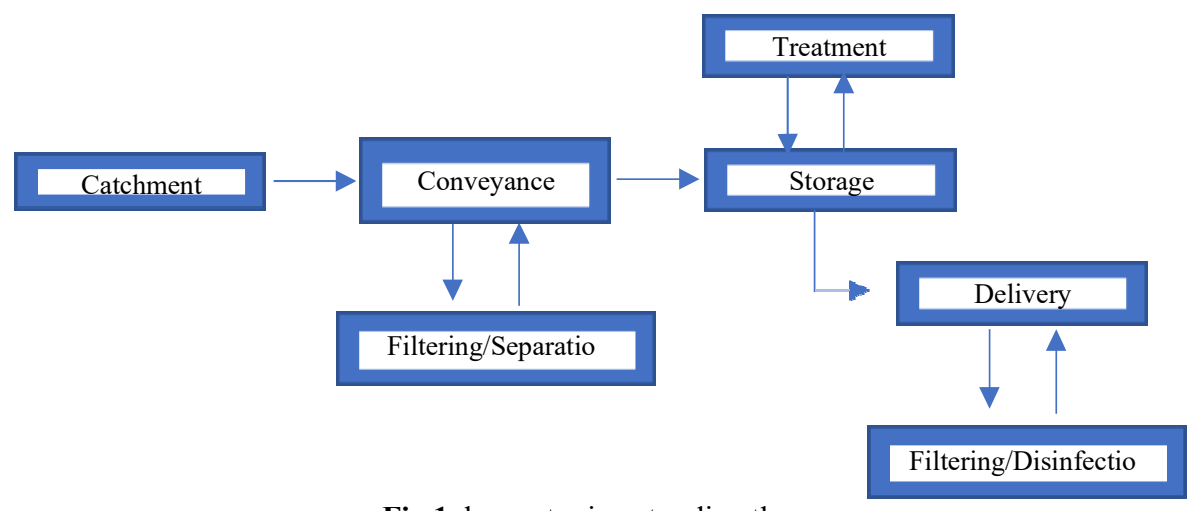

Fig.1. harvest rainwater directly

\subsection{Calculation Analysis}

Calculation analysis is done through the processing of raw data obtained from the Office of Public Spatial Planning (PUPR) of Bekasi City, Perum Jasa Tirta II of Bekasi City from monitoring rainfall data. By calculating or determining the average rainfall:

Table 1. Data on Maximum Rainfall of Bekasi Dam Station Rainfall Data for the Last 10 Years (2007-2017).

\begin{tabular}{|c|c|c|c|c|c|c|c|c|c|c|c|c|c|}
\hline \multirow[t]{2}{*}{ Year } & \multicolumn{13}{|c|}{ Month } \\
\hline & Jan & Feb & Mar & Apr & May & Jun & Jul & Aug & Sep & Oct & Nov & Dec & CH Ma (Xi) \\
\hline 2007 & 290.00 & 732.00 & 152.00 & 361.00 & 97.00 & 92.00 & 2.00 & 13.00 & 6.00 & 88.00 & 202.00 & 279.00 & 732.00 \\
\hline 2008 & 108.00 & 585.00 & 258.00 & 169.00 & 40.00 & 37.00 & 12.00 & 20.00 & 31.00 & 65.00 & 110.00 & 103.00 & 585.00 \\
\hline 2009 & 198.00 & 302.00 & 144.00 & 2.00 & 89.00 & 65.00 & 5.00 & 22.50 & 54.00 & 22.00 & 164.00 & 227.00 & 302.00 \\
\hline 2010 & 318.00 & 265.00 & 130.00 & 70.00 & 86.00 & 102.00 & 19.00 & 51.00 & 165.00 & 28.00 & 120.00 & 49.00 & 318.00 \\
\hline 2011 & 74.00 & 52.00 & 35.00 & 81.00 & 155.00 & 29.00 & 3.00 & 6.00 & 6.00 & 25.00 & 38.00 & 186.00 & 186.00 \\
\hline 2012 & 209.00 & 298.00 & 168.00 & 120.00 & 18.00 & 18.00 & 0.00 & 0.00 & 22.00 & 0.00 & 196.00 & 303.00 & 303.00 \\
\hline 2013 & 447.00 & 256.00 & 124.00 & 60.00 & 219.00 & 87.00 & 272.00 & 32.00 & 64.00 & 99.00 & 116.00 & 440.00 & 447.00 \\
\hline 2014 & 827.00 & 408.00 & 218.00 & 131.00 & 91.00 & 108.00 & 55.00 & 5.00 & 5.00 & 0.00 & 118.00 & 120.00 & 827.00 \\
\hline 2015 & 197.00 & 332.00 & 139.00 & 101.00 & 47.00 & 8.00 & 0.00 & 0.00 & 5.00 & 0.00 & 53.00 & 115.00 & 332.00 \\
\hline 2016 & 106.00 & 187.00 & 119.00 & 64.00 & 194.00 & 72.00 & 116.00 & 127.00 & 9.00 & 243.00 & 106.00 & 166.00 & 243.00 \\
\hline 2017 & 151.00 & 103.00 & 30.00 & 55.00 & 90.00 & 40.00 & 0.00 & 0.00 & 0.00 & 39.00 & 82.00 & 193.00 & 193.00 \\
\hline
\end{tabular}


Table 2. Data on Maximum Rainfall of Setu Station Rainfall Data for the Last 10 Years (2007-2017)

\begin{tabular}{ccccccccccccccc}
\hline \multirow{2}{*}{ Year } & \multicolumn{1}{c}{ Jan } & Feb & Mar & Apr & May & Jun & Jul & Aug & Sep & Oct & Nov & Dec & CH Ma (Xi) \\
& & & & & & & & & & & & & \\
\hline 2007 & 89.00 & 555.00 & 120.00 & 263.00 & 168.00 & 77.00 & 16.00 & 0.00 & 8.00 & 71.00 & 112.00 & 319.00 & 555.00 \\
2008 & 102.00 & 507.00 & 187.00 & 302.00 & 116.00 & 9.00 & 6.00 & 6.00 & 0.00 & 86.00 & 118.00 & 46.00 & 507.00 \\
2009 & 198.00 & 128.00 & 183.00 & 26.00 & 45.00 & 84.00 & 35.00 & 56.00 & 63.00 & 0.00 & 150.00 & 226.00 & 226.00 \\
2010 & 295.00 & 459.00 & 338.00 & 123.00 & 252.00 & 228.00 & 105.00 & 199.00 & 602.00 & 730.00 & 222.00 & 280.00 & 730.00 \\
2011 & 172.00 & 202.00 & 84.00 & 374.00 & 189.00 & 20.50 & 9.50 & 19.00 & 19.00 & 130.00 & 150.00 & 258.00 & 374.00 \\
2012 & 320.00 & 226.00 & 186.00 & 310.00 & 40.00 & 132.00 & 16.50 & 0.00 & 53.00 & 42.00 & 448.00 & 453.00 & 453.00 \\
2013 & 449.00 & 247.00 & 305.00 & 58.00 & 230.00 & 50.00 & 259.00 & 37.00 & 0.00 & 123.00 & 178.00 & 392.00 & 449.00 \\
2014 & 786.00 & 384.00 & 217.00 & 322.00 & 308.00 & 191.00 & 184.00 & 70.50 & 30.50 & 136.00 & 247.00 & 228.00 & 786.00 \\
2015 & 248.00 & 354.00 & 139.00 & 101.00 & 47.00 & 8.00 & 0.00 & 0.00 & 9.00 & 0.00 & 53.00 & 116.00 & 354.00 \\
2016 & 224.00 & 371.00 & 310.00 & 254.00 & 195.00 & 186.00 & 155.00 & 174.00 & 307.00 & 197.00 & 181.00 & 133.00 & 371.00 \\
2017 & 197.00 & 332.00 & 139.00 & 101.00 & 47.00 & 8.00 & 0.00 & 0.00 & 5.00 & 0.00 & 53.00 & 115.00 & 332.00 \\
\hline
\end{tabular}

Tabel 3. Data on Maximum Rainfall of Cibitung Station Rainfall Data for the Last 10 Years (2007-2017)

\begin{tabular}{|c|c|c|c|c|c|c|c|c|c|c|c|c|c|}
\hline \multirow[t]{2}{*}{ Year } & \multicolumn{13}{|c|}{ Month } \\
\hline & Jan & Feb & Mar & Apr & May & Jun & Jul & Aug & Sep & Oct & Nov & Dec & CH Ma (Xi) \\
\hline 2007 & 500.00 & 724.00 & 156.00 & 289.00 & 89.90 & 104.00 & 0.00 & 19.90 & 1.20 & 104.00 & 110.00 & 321.00 & 724.00 \\
\hline 2008 & 124.00 & 582.00 & 149.00 & 124.00 & 49.00 & 30.00 & 5.00 & 8.00 & 0.00 & 75.00 & 44.00 & 74.00 & 582.00 \\
\hline 2009 & 304.00 & 233.00 & 101.00 & 75.00 & 48.00 & 80.40 & 0.00 & 32.20 & 3.00 & 0.00 & 96.50 & 177.00 & 304.00 \\
\hline 2010 & 442.00 & 223.00 & 70.00 & 116.00 & 40.00 & 147.00 & 10.00 & 69.00 & 2002.00 & 349.00 & 150.00 & 118.00 & 2002.00 \\
\hline 2011 & 151.00 & 103.00 & 30.00 & 55.00 & 90.00 & 40.00 & 0.00 & 0.00 & 0.00 & 39.00 & 82.00 & 193.00 & 193.00 \\
\hline 2012 & 355.00 & 130.00 & 229.00 & 270.00 & 32.00 & 60.00 & 0.00 & 0.00 & 0.00 & 0.00 & 80.00 & 220.00 & 355.00 \\
\hline 2013 & 637.00 & 232.00 & 89.00 & 168.00 & 224.00 & 70.00 & 89.00 & 14.00 & 7.00 & 58.00 & 0.00 & 88.00 & 637.00 \\
\hline 2014 & 317.00 & 494.00 & 65.00 & 151.00 & 173.00 & 147.00 & 147.00 & 20.00 & 0.00 & 0.00 & 152.00 & 127.00 & 494.00 \\
\hline 2015 & 257.00 & 263.00 & 100.00 & 114.00 & 26.00 & 17.00 & 0.00 & 0.00 & 0.00 & 0.00 & 35.00 & 86.00 & 263.00 \\
\hline 2016 & 13.00 & 18.00 & 19.00 & 9.00 & 0.00 & 0.00 & 0.00 & 0.00 & 0.00 & 5.00 & 11.00 & 14.00 & 19.00 \\
\hline 2017 & 169.00 & 394.00 & 79.00 & 111.00 & 103.00 & 82.00 & 138.00 & 164.00 & 221.00 & 256.00 & 292.00 & 14.00 & 394.00 \\
\hline
\end{tabular}

The comparison between raw water demand and rainwater supply is obtained from the merging of the calculated data with the Analysis data

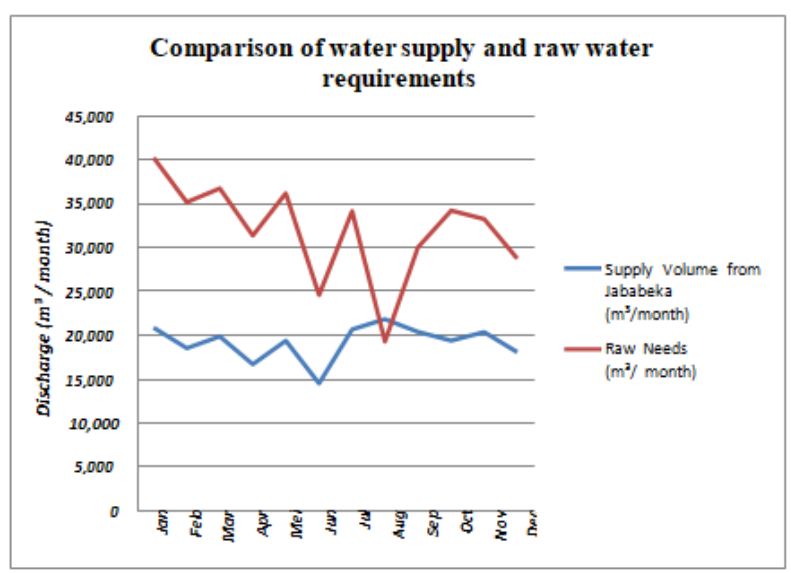

Fig.2. Comparison of water supply and raw water requirements 


\subsection{Hidrology}

Rainfall data in this study uses monthly rainfall data from 3 rainfall recording stations with a period of 10 years from 2007 to 2017. These data were obtained from Division 1 of Perum Jasa Tirta II Bekasi City. The data of the three stations used are the closest rainfall stations to the location of the study, namely the Bekasi Dam Rainfall Station, Setu Rainfall Station and Cibitung Rainfall Station. The following is the rainfall data, which is: Calculation of the Rain Plan Logarithm. Rumus:

$\log \mathrm{RT}=\log \mathrm{Xi}$ Rata $2+\left(\mathrm{K}^{*} \mathrm{STDEV} \log \mathrm{Xi}\right)$

$\mathrm{r}=(\mathrm{R} 24 / 24)^{*}(24 / \mathrm{t})^{\wedge}(2 / 3)$

RT $=\operatorname{POWER}(10 ; .$.

Table 4. Rainfall Analysis (Log Person)

\begin{tabular}{cccccc}
\hline Year & $\mathbf{X i}$ & $\log \mathbf{X i}$ & $\log \mathbf{X i - l o g} \mathbf{X}$ & $(\log \mathbf{X i -} \log \mathbf{X})^{2}$ & $(\log \mathbf{X i -}-\log \mathbf{X})^{\mathbf{3}}$ \\
\hline 2007 & 724 & 2.8597 & 0.3109 & 0.0967 & 0.0301 \\
2008 & 582 & 2.7649 & 0.2161 & 0.0467 & 0.0101 \\
2009 & 304 & 2.4829 & -0.0659 & 0.0043 & -0.0003 \\
2010 & 2002 & 3.3015 & 0.7527 & 0.5665 & 0.4264 \\
2011 & 193 & 2.2856 & -0.2632 & 0.0693 & -0.0182 \\
2012 & 355 & 2.5502 & 0.0014 & 0 & 0 \\
2013 & 637 & 2.8041 & 0.2553 & 0.0652 & 0.0166 \\
2014 & 494 & 2.6937 & 0.1449 & 0.021 & 0.003 \\
2015 & 263 & 2.42 & -0.1288 & 0.0166 & -0.0021 \\
2016 & 19 & 1.2788 & -1.2701 & 1.613 & -2.0486 \\
2017 & 394 & 2.5955 & 0.0467 & 0.0022 & 0.0001 \\
\hline TOTAL & $\mathbf{2 8 . 0 3 6 9}$ & \multicolumn{3}{c}{} & $\mathbf{- 1 . 5 8 3}$ \\
\hline
\end{tabular}

\subsection{Calculation of Rainwater Discharge That Can be Harvested}

Layout map of Skin Deo Factory Cikarang is used to determine the type of building roof to determine runoff coefficient (A) and catchment area in the form of a roof. The coefficient (k), rainfall (R) and catchment area that are known are used to calculate the volume of collected rainwater, with the following equation.

$\mathrm{V}=\mathrm{R} . \mathrm{A} \cdot \mathrm{K}$

Rainwater Discharge, the method used to calculate rainwater discharge in a channels in this study is the rational method of USSCS (1973). The general form of this equation is as follows [18]:

$\mathrm{Q}=$ Qah. C. I. A.

$\mathrm{Q}=$ flood discharge plan $\mathrm{Qah}=0,00278 \mathrm{C} \mathrm{I} \mathrm{A} \mathrm{m} 3 / \mathrm{s}$

$\mathrm{C}=$ run off coeficient (industrial weight area $=0,60-0,90) \mathrm{I}=$ rain intensity for a constant time $(\mathrm{mm} / \mathrm{h})$

$\mathrm{A}=$ catchment area of the roof (ha) 


$$
\begin{aligned}
\text { Q } & =\text { Qah. C. I. A } \\
& =0.00278 \times 0,90 \times 26,137 \times 42,558 \\
& =0,0042558 \text { ha } \\
& =0,0223 \mathrm{~m}^{3} / \mathrm{s} \text { (total runoff discharge) }
\end{aligned}
$$

\begin{tabular}{|c|c|c|c|c|c|c|c|c|c|c|c|}
\hline Month & $\begin{array}{l}\text { Number } \\
\text { of days }\end{array}$ & $\begin{array}{c}\text { Average } \\
\text { (mm) }\end{array}$ & $\begin{array}{c}\text { Roof Area } \\
\quad\left(\mathbf{m}^{2}\right)\end{array}$ & $\begin{array}{c}\text { Total Water } \\
\text { Needs }\left(\mathrm{m}^{3} / \mathbf{h r}\right)\end{array}$ & $\begin{array}{l}\text { Koef } \\
\text { Run off }\end{array}$ & $\begin{array}{c}\text { Water } \\
\text { supply } \\
\text { Rain } \\
\left(\mathbf{m}^{3}\right)\end{array}$ & $\begin{array}{c}\text { Total } \\
\text { Water } \\
\text { Needs } \\
100 \%\left(\mathbf{m}^{3}\right)\end{array}$ & $\begin{array}{c}\text { Total } \\
\text { Water } \\
\text { Needs 70\% } \\
\left(\mathbf{m}^{3}\right) \\
\end{array}$ & $\begin{array}{c}\text { Deficiency } \\
\left(\mathrm{m}^{3}\right)\end{array}$ & $\begin{array}{c}\text { Advantages } \\
\qquad\left(\mathbf{m}^{3}\right)\end{array}$ & Explanation \\
\hline $\mathbf{A}$ & B & C & D & $\mathbf{E}$ & $\mathbf{F}$ & G & H & I & $\mathbf{J}$ & $\mathbf{K}$ & 1 \\
\hline Jan & 31 & 169 & 42.558 & 20.883 & 0.9 & 799.865 & 647.373 & 453.161 & 317.213 & 222.049 & \multirow{12}{*}{$\begin{array}{c}\mathrm{e}=\text { Obtained } \\
\text { from the } \\
\text { Table } \\
\mathrm{g}=\mathrm{c} \times \mathrm{d} \times \mathrm{f} \\
\mathrm{h}=\mathrm{b} \times \mathrm{e} \\
\mathrm{j}=\mathrm{h}>\mathrm{gk}= \\
\mathrm{g}>\mathrm{h}\end{array}$} \\
\hline Feb & 28 & 394 & 42.558 & 18.542 & 0.9 & 710.199 & 519.176 & 363.423 & 254.396 & 178.077 & \\
\hline Mar & 31 & 79 & 42.558 & 19.868 & 0.9 & 760.988 & 615.908 & 431.136 & 301.795 & 211.256 & \\
\hline Apr & 30 & 111 & 42.558 & 16.704 & 0.9 & 639.8 & 501.12 & 350.784 & 245.549 & 171.884 & \\
\hline May & 31 & 103 & 42.558 & 19.391 & 0.9 & 742.718 & 601.121 & 420.785 & 294.549 & 206.185 & \\
\hline Jun & 30 & 82 & 42.558 & 14.52 & 0.9 & 556.148 & 435.6 & 304.92 & 213.444 & 149.411 & \\
\hline Jul & 31 & 138 & 42.558 & 20.656 & 0.9 & 791.17 & 640.336 & 448.235 & 313.765 & 219.635 & \\
\hline Aug & 31 & 164 & 42.558 & 21.844 & 0.9 & 836.673 & 677.164 & 474.015 & 331.81 & 232.267 & \\
\hline Sep & 30 & 221 & 42.558 & 20.395 & 0.9 & 781.173 & 611.85 & 428.295 & 299.807 & 209.865 & \\
\hline Oct & 31 & 256 & 42.558 & 19.411 & 0.9 & 743.484 & 601.741 & 421.219 & 294.853 & 206.397 & \\
\hline Nov & 30 & 292 & 42.558 & 20.369 & 0.9 & 780.178 & 611.07 & 427.749 & 299.424 & 209.597 & \\
\hline Dec & 31 & 14 & 42.558 & 18.092 & 0.9 & 692.963 & 560.852 & 392.596 & 274.817 & 192.372 & \\
\hline
\end{tabular}

Table 5. Calculation of PAH capacity for Cibitung Rain Station with a Total Raw Water Need of $70 \%$

\subsection{Storage Capacity Of Rainwater Harvesting}

Tank Volume Calculation for Rainwater Harvesting, or Rainwater Harvesters in Skin Deo Factory Cikarang Factory Skin Deo Factory has a shape like Figure 4.3. The shape of the building Harvesting rainwater with the building volume in the form of a trapezoid, so here I use the trapezoid formula where the size is in accordance with the existing in the picture.

$$
\begin{aligned}
\mathrm{a} & =6400+3500+3500 \mathrm{~mm} \\
& =13400 \mathrm{~mm} \square 13,4 \mathrm{~m} \\
\mathrm{~b} & =6400 \mathrm{~mm} \square 6,4 \mathrm{~m} \mathrm{t} \\
& =3500 \mathrm{~mm} \square 3,5 \mathrm{~m} \mathrm{l}=20000 \mathrm{~mm} \square 20 \mathrm{~m} \\
\mathrm{~V} & =20 \times 9,9 \times 3 \\
& =693 \mathrm{~m}^{3}
\end{aligned}
$$

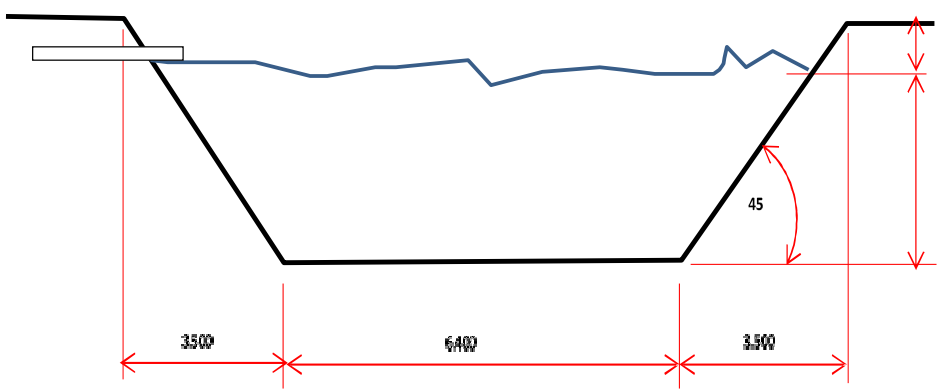

Fig. 3. Rainwater Harvesting Building Shape 
$V$ tank $=$ V rainy season supply

$=\frac{500+724+156+289+104+110+321}{8}$
$=288,3 \mathrm{~m}^{3}=300 \mathrm{~m}^{3}$

After calculating the capacity of the rainwater harvesting tank, the monthly water balance can be calculated as in the following Table 10 .

Table 6. Water Balance Reservoir

\begin{tabular}{ccccc}
\hline Month & Supply (m3) & Initial (m3) & First Annual Requirement (m3) & Final (m3) \\
\hline Jan & 169.0 & 143 & 250 & 62.0 \\
Feb & 394.0 & 430 & 250 & 574.0 \\
Mar & 79.0 & 362 & 250 & 191.0 \\
Apr & 111.0 & 261 & 250 & 122.0 \\
May & 103.0 & 327 & 250 & 180.0 \\
Jun & 82.0 & 263 & 250 & 95.0 \\
Jul & 138.0 & 151 & 250 & 39.0 \\
Aug & 164.0 & 904 & 250 & 818.0 \\
Sept & 221.0 & 474 & 250 & 445.0 \\
Oct & 256.0 & 589 & 250 & 595.0 \\
Nov & 292.0 & 519 & 250 & 561.0 \\
Dec & 14.0 & 346 & 250 & 110.0 \\
& 2023 & & 3000 & \\
\hline
\end{tabular}

\subsection{Evaluation of Rainwater Harvesting Planning Results}

Results of the evaluation of rainwater harvesting planning at Skin Deo Factory Cikarang, Tbk. with a $600 \mathrm{~m}^{3}$ capacity plan can be shown in Table 11 .

Table 7. Rainwater Harvesting Planning At Skin Deo Factory Cikarang

\begin{tabular}{ll}
\hline \multicolumn{1}{c}{ Plan } & \multicolumn{1}{c}{ Results } \\
\hline Design criteria capacity $600 \mathrm{~m}^{3}$. & $\begin{array}{l}\text { From the calculation data for the In accordance with the } \\
\text { needs of this shelter is equal to needs of the conditions }\end{array}$ \\
& $\mathbf{2 8 8 . 3} \mathbf{m}^{\mathbf{3}}=\mathbf{3 0 0} \mathbf{m}^{3}$. in the area and enough \\
Depending on the needs by to covered the needs. \\
looking at the actual \\
conditions using calculations, \\
with the current actual condition \\
$1 / 2$ of the maximum capacity can \\
still \\
be covered.
\end{tabular}




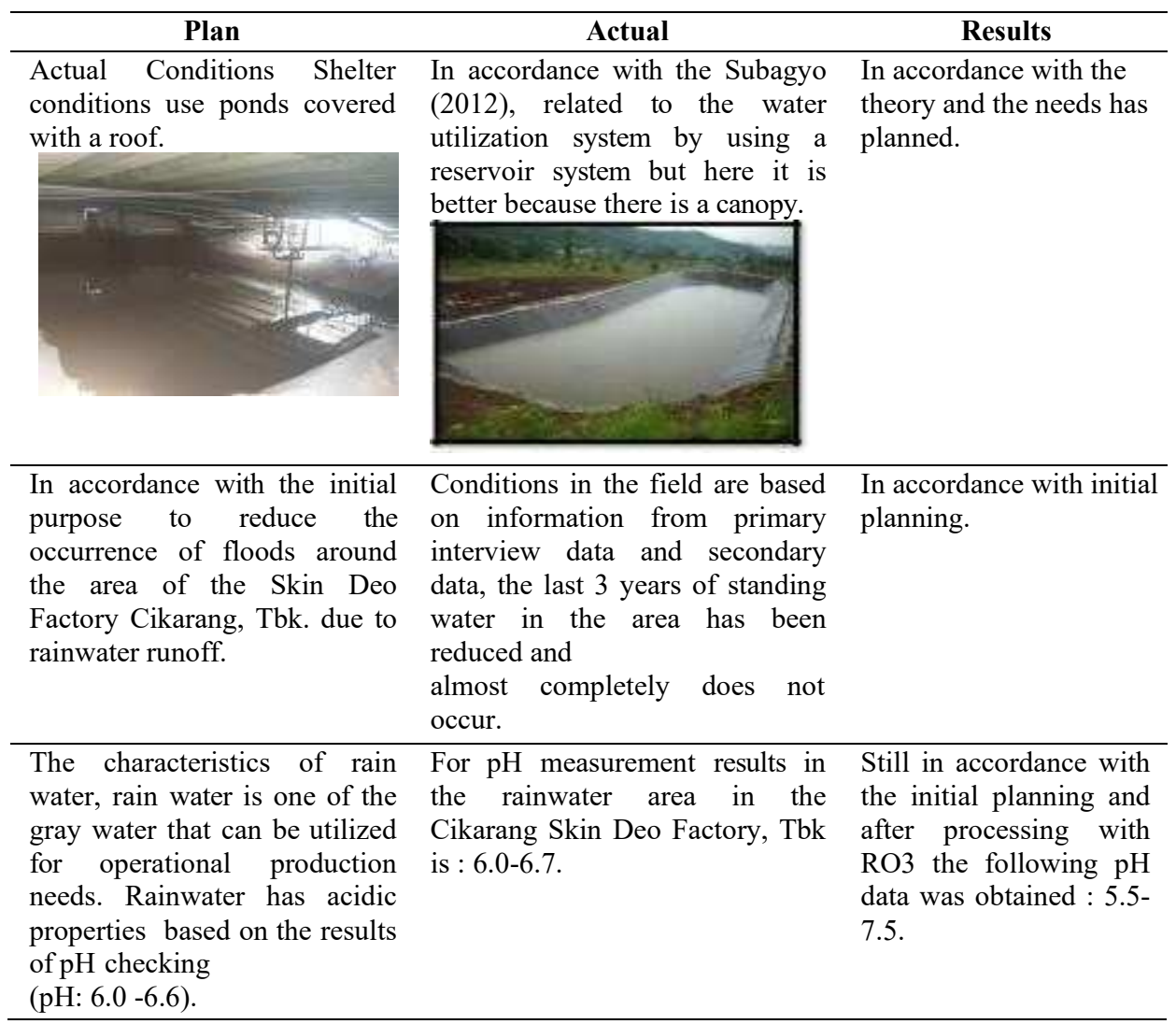

\section{Conclusion}

There are several conclusions that we can draw from the results of "Rainwater Harvesting as an alternative in Water Resources Management as follows:

a) With a catchment area of $42,558 \mathrm{~m}^{2}$ obtained Debit $=0.0223 \mathrm{~m}^{3} / \mathrm{s}$ with Effective Tank Volume $=288.3 \mathrm{~m} 3 \approx 300 \mathrm{~m}^{3}$,

b) In the form of a trapezoidal reservoir with the design according to Figure 4.3, the volume of water collected in the reservoir is in accordance with the design criteria,

c) The amount of rainwater that can be collected on the roof of the factory with initial storage tank capacity of $600 \mathrm{~m}^{3}$ with actual capacity, currently the holding tank only holds $288.3 \mathrm{~m}^{3}=300 \mathrm{~m}^{3}$ which can meet the total needs of $61 \%$ per month and can save water use $39 \%$ monthly,

d) The initial criteria for collecting rainwater is $600 \mathrm{~m}^{3}$ in design. Placement of underground rainwater harvesting reservoirs with a ground water system and with the help of pumps and temporary storage tanks, water can be channeled above and utilized for the needs of town water that was previously through the process of RO (Reverse 
Osmosis),

e) Utilization of rainwater harvesting within factory very helpful in the operational process where is used to supply cooling towers in the packing hall and amenitis / bathroom areas,

f) In Harvesting rainwater in Skin Deo Factory Cikarang, Tbk., the water threat that is used is very simple, namely: Filtering of solid material, Sedimentation of mud, Absorption and then processed using the RO system.

g) rainwater obtained by filtering results in this designed technology, the $\mathrm{pH}$ value and parameters for the standard can even be used for drinking water and can be utilized without exceeding the permitted levels based on Group B / Category 1 standards set by the Ministry of Health.

\section{References}

[1] Simeonov, V., Stratis, J., Samara, C., Zachariadis, G., Voutsa, D., Anthemidis, A., et al., 2003. Assesment of The Surface Water Quality in Northern Greece. Water Res. 37 (17), 4119-4124

[2] Silva, C.M. Sousa, V., Carvalho, N.V., 2015. Evaluation of rainwater harvesting in Portugal: application to single-family residences. Resour. Conserv. Recycl. 94, 21- 34.

[3] Eroksuz, E., Rahman, A., 2010. Rainwater tanks in multi-unit buildings: a case study for three Australian cities. Resour. Conserv. Recycl. 54 (12), 1449-1452.

[4] Imteaz, M.A., Rahman, A., Ahsan, A., 2012. Reliability analysis of rainwater tanks: a comparison between South-East and Central Melbourne. Resour. Conserv. Recycl. 66, 1-7.

[5] Imteaz, M.A., Ahsan, A., Rahman, A., Mekanik, F., 2013. Modelling stormwater treatment systems using MUSIC: Accuracy. Resour. Conserv. Recycl. 71, 15-21.

[6] Haque, M.M., Rahman A., Samali B., 2016. evaluation of climate change impact s on rainwater harvesting. Journal of Cleaner Production. 137, 60-69.

[7] Harsoyo, B. 2010. Teknik Pemanen Air Hujan (Pemanenan Air Hujan) sebagai Alternatif Upaya Penyelamatan Sumber Daya Air di Wilayah DKI jakarta. Jurnal Sains dan Teknologi Modifikasi Cuaca, Vol. 11, No. 2, 2010:29-39

[8] Herrmann, T., Schmida, U., 2000. Rainwater utilisation in Germany: efficiency, dimensioning, hydraulic and environmental aspects. Urban water 1 (4), 307-316.

[9] Fengtai, G., Xiaochao, M., 2012. Study on rainwater utilization engineering mode in northern cities of China. Proced. Eng. 28, 453e457.

[10] Ghisi E., Ferreira, D.F., 2007. Potential for potable water savings by using rainwater and greywater in a multi-storey residential building in southern Brazil. Build. Environ. 42 (7), 25122522.

[11] Aladenola, O.O., Adeboye, O.B., 2010. Assessing the potential for rainwater harvesting. Water Resour. Manag. 24 (10), 2129-2137.

[12] Steffen, J., Jensen, M., Pomeroy, C.A., Burian, S.J., 2013. Water supply and stormwater management benefits of residential rainwater harvesting in US cities. JAWRA J.Am. Water Resour. Assoc. 49 (4), 810-824.

[13] Palla, A., Gnecco, I., Lanza, L., La Barbera, P., 2012. Performance analysis of domestic rainwater harvesting systems under various European climate zones.

Resour. Conserv. Recycl. 62, 71-80.

[14] Sample, D.J., Liu, J., 2014. Optimizing rainwater harvesting systems for the dual purposes of water supply and runoff capture. J. Clean. Prod. 75, 174-194.

[15] García-Montoya, M., Sengupta, D., Na poles-Rivera, F., Ponce-Ortega, J.M., El- Halwagi, M.M., 2015. Environmental and economic analysis for the optimal reuse of water in a residential complex. J. Clean. Prod. 130, 82-91. 
[16] Imteaz, M.A., Ahsan, A., Naser, J., Rahman, A., 2011a. Reliability analysis of rainwater tanks in Melbourne using daily water balance model. Resour. Conserv. Recycl. 56 (1), 80-86.

[17] Rahman, A., Keane, J., Imteaz, M.A., 2012. Rainwater harvesting in Greater Sydney: water savings, reliability and economic benefits. Resour. Conserv. Recycl. 61, 16-21.

[18] Suripin. 2004. Sistem Drainase yang Berkelanjutan. Penerbit Andi Offset, Yogyakarta

[19] Heryani, Nani. 2009. Teknik Panen Hujan : Salah Satu Alternatif Untuk Memenuhi Kebutuhan Air Domestik, Balai Penelitian Agroklimat dan Hidrologi, Departemen Pertanian. Jakarta. 